\title{
Labour Disputes and the Game of Legal Representation
}

\author{
Henri Fraisse
}

CESIFO WORKING PAPER No. 3084

CATEGORY 4: LABOUR MARKETS

JUNE 2010
An electronic version of the paper may be downloaded
- from the SSRN website: Www.SSRN.com
- from the RePEc website: Www.RePEc.org
- from the CESifo website: www.CESifo-group.org/wp




\title{
Labour Disputes and the Game of Legal Representation
}

\begin{abstract}
This paper explores the prisoner's dilemma that may result when workers and firms are involved in labour disputes and must decide whether to hire a lawyer to be represented at trial. Using a representative data set of labour disputes in the UK and a large population of French unfair dismissal cases, we find that a lawyer substantially increases the firm's probability of winning at trial but has little effect on the worker's victory probability. The UK data contain award and litigation costs and allow us to compute the pay-off matrix. We do not find evidence of a prisoner's dilemma, given that the total pay-off for the worker is not significantly different whether she is represented or not. Surprisingly, the dominant strategy for the firm is not to be represented.
\end{abstract}

JEL-Code: J52, J53, K41.

Keywords: litigation, lawyers, labour dispute resolution, prisoner's dilemma.

\author{
Henri Fraisse \\ Banque de France \\ 31 Rue Croix-des-Petits Champs \\ France- 75001 Paris \\ hf42@cornell.edu
}

The UK data used in the paper were collected by BMRB (2003 wave) and by the National Centre for Social Research (1998 wave) on behalf of the Department of Trade and Industry, the Advisory, Conciliation and Arbitration Service and the Scottish Executive, and were made available by the UK Data Archive at the University of Essex, to whom applications for copies of the data should be made. The French data used in this paper were collected by the French Ministry of Justice. I thank Larry Kahn, John Abowd and Jed DeVaro for their helpful comments. All views expressed, together with any errors or omissions are the responsibility of the author alone. 


\section{Introduction}

About 200,000 unfair dismissal cases are filed every year in France and around 100,000 in the United Kingdom. This accounts for 10 percent of the people claiming unemployment-related benefits in the UK, and represents about 30 percent of the yearly number of workers enrolling at the National Placement Agency in France after having been fired. In addition to the award or the settlement amount, legal representation might represent a substantial firing cost for the firm. As noted by Blanchard and Tirole (2004), judges' interventions are necessary to distinguish redundancy from misconduct, denounce discrimination or verify that all the legal requirements surrounding a redundancy case have been followed. However, labour legislation often substitutes the judgement of court judge for that of the company's management, which is economically inefficient. For example, the judicial process relating to firing decisions has been offered as an explanation for the poor performance of the French labour market. Hence, any reform pushing toward greater conciliation and fewer judicial battles in the firing decision is a matter of importance for the policy maker and the role of legal representation must be scrutinised. There are numerous tools available to the policy maker for reaching this goal: caps on awards, allocations of legal costs to the losing party, mandatory and preliminary use of an arbitrator to make steps towards conciliation and so on. They would be particularly justified if legal representation is chosen and turns out to be a sunk cost.

There is no doubt that a lawyer is necessary in many cases: in criminal cases a lawyer is usually appointed by the court when the defendant cannot obtain or pay for an attorney. However, whether or not to pay for legal representation is a matter of cost-benefit analysis and strategic choice for a wide range of legal conflicts. Each party might trade off legal fees against lower expectations of winning at trial, assuming that legal assistance is not detrimental. The return on hiring a lawyer might also be influenced by whether the other party hires one. If one party hires a lawyer in an effort to increase the chances of success, and the other party does the same, the likelihood of victory might ultimately be the same as if neither party was represented. Following this logic, Ashenfelter and Bloom (1990) were the first to formally observe that strategic behaviour in choosing legal representation might result in a prisoner's dilemma game. A dominant strategy for both parties is to choose a lawyer to be represented, but in doing so they end up being worse off than if they had not been represented. Taking the example of a union and a firm bargaining over a wage increase, both parties might neutralise the actions of their opponent if they both use a lawyer or if they both do not use a lawyer. On the other hand, if only the worker (firm) uses a lawyer, an additional wage increase (decrease) is achieved. 
We can write the pay-off matrix as:

\begin{tabular}{|c|c|c|c|}
\cline { 3 - 3 } \multicolumn{2}{c|}{} & \multicolumn{2}{c|}{ Defendant uses: } \\
\cline { 3 - 4 } Plaintiff uses: & A lawyer & $\Pi_{l, l}^{p}, \Pi_{l, l}^{d}$ & $\Pi_{l, n l}^{p}, \Pi_{l, n l}^{d}$ \\
\cline { 2 - 4 } & No Lawyer & $\Pi_{n l, l}^{p}, \Pi_{n l, l}^{d}$ & $\Pi_{n l, n l}^{p}, \Pi_{n l, n l}^{d}$ \\
\hline
\end{tabular}

Matrix pay-off of the game of legal representation

where $\Pi_{i, j}^{k}$ is the pay-off with $k=p$ (plaintiff) or $d$ (defendant) and $i(j)$ indicates the representation of the plaintiff (defendant) with $l$ for lawyer and $n l$ for no lawyer. The necessary conditions for the prisoner's dilemma are that $\Pi_{l, l}^{p} \geq \Pi_{n l, l}^{p}, \Pi_{l, n l}^{p} \geq \Pi_{n l, n l}^{p}\left(\Pi_{l, l}^{d} \geq \Pi_{l, n l}^{d}, \Pi_{n l, l}^{d} \geq \Pi_{n l, n l}^{d}\right)$ for the worker (firm) to choose to be represented and $\Pi_{l, l}^{p} \leq \Pi_{n l, n l}^{p}, \Pi_{l, l}^{d} \leq \Pi_{n l, n l}^{d}$ for the parties' incentives to lead to the low equilibrium. Hereafter, we call (L,L) the case for which both parties are represented, (NL,NL) the case for which neither party is represented, (L,NL) the case for which the worker is represented but not the firm, and (NL,L) the case for which the firm but not the worker is represented.

Only a few empirical studies analyse the gain from hiring a lawyer ${ }^{3}$. Even fewer consider it as a strategic choice in a two-player game. Using a sample of grievance arbitration awards, Block and Stieber (1987) find that the outcome of the arbitration does not differ when both parties are represented by an attorney versus when neither of the parties is represented. The probability of prevailing increases only when one party hires an attorney and the other party does not. Ashenfelter and Bloom (1990), Wagar (1994), Ashenfalter and Dahl (2009) report similar findings. More recently, Halla (2007), using data on divorce cases, finds that hiring a lawyer is beneficial for the wife only if the husband is not represented. The data sets used by these authors suffer from some limitations. Except for Halla (2007), they take into account only cases solved through arbitration and not through the court system. They are specific and not representative of the population of cases: Block and Stieber (1987) use a sample of 454 cases recorded in Michigan and 759 cases published by the Bureau of National Affairs during the years 1979-1981. Ashenfelter and Bloom (1990) exploit a data set containing 217 union-employer cases resolved by final-offer arbitration in New Jersey between 1981 and 1984. Halla (2007), who offers a more comprehensive data set, employs 2,436 divorce cases taken from five district courts in Austria between 1997 and 2003. Moreover, these data sets, as is usual in the legal empirical literature, share the common failing of lacking measures of the intrinsic quality of cases and they only offer limited information on the plaintiffs and defendants' characteristics to limit the bias arising from it. ${ }^{4,5}$ Finally and most importantly, these papers empirically find the necessary

\footnotetext{
${ }^{3}$ Latreille et al. (2005) using a survey of Employment Tribunals representative of 1998 analyse the impact of representatives on case outcomes. However, due to the small sample size, they are only able to provide a descriptive analysis.

${ }^{4}$ In this paper, a case is considered to be of "good quality" from the perspective of the plaintiff.
} 
conditions for having a prisoner dilemma in terms of probability of victory ${ }^{6}$. Nevertheless, as they do not provide any information on legal fees, they do not allow for the computation of the game's pay-off matrix and the question of whether the game leads to a prisoner's dilemma remains unanswered.

In this paper, we complement these studies by using two data sets describing unfair dismissals brought to courts in France and the UK. The French data set is comprised of administrative records of almost 2,000,000 cases that have been brought to labour court from 1990 to 2004. Unfortunately, awards and legal fees are unavailable, but the data allow us to compute the matrix of marginal probabilities of victory on a population of cases. The UK data set is comprised of two successive samples of UK Employment Tribunal cases drawn in 1998 and 2003, containing rich information on the plaintiff and the defendant, including the settlement amount, the award in of the event of trial, legal representation and its cost, and in the event of a tribunal hearing, the characteristics of the representation of the other party. Therefore, they allow us to compute the pay-off matrix.

\section{Data Sets and Descriptive Statistics}

\section{The UK case}

In the United Kingdom, the Employment Tribunals (ET hereafter) have been in charge of adjudicating disputes between employers and individual workers since the Redundancy Payment Act of 1965. They acquired jurisdiction over unfair dismissals with the Industrial Relations Act of 1971. The trial is chaired by a professional judge assisted by two lay-members- one with an employer background and the other with a trade union or employee representative background. The lay judges are chosen by the administration from lists of persons proposed mainly by trade unions and employer groups.

Surveys of unfair dismissal have been conducted about every five years since 1975. Until 1998 samples were comprised of, on average, 650 matched cases where both the employer and applicant were interviewed. Each case can be withdrawn, settled or go to a full hearing. Over the last two waves, about 20 percent of the cases went to a full hearing. Information on whether the other party has legal representation is available only for cases that reached the trial stage. In order to get a sample large enough for a statistically robust analysis, we use the 1998 and 2003 waves of the Survey of Employment Tribunal Applications series. These waves do not represent a sample of matched cases. The 2003 wave is composed of a random sample of 4,517 cases divided into two independent samples of applicants (2,236 cases) and employers (2,281 cases). Each of the 2003 samples were drawn across all jurisdictions from tribunal cases completed between March 2002 and March 2003. Both samples

\footnotetext{
${ }^{5}$ Farber and White (1991) is the only study I am aware of that provides such a measure.

${ }^{6}$ In the event of arbitration, the winning side is the one whose proposal is the closest to the proposal of the arbitrator.
} 
are representative of cases completed in The United Kingdom during this period. The 1998 wave is also composed of two independent samples of applicants (1,384 cases) and employers (1,292 cases) representative of cases that have been registered between January 1995 and April 1997.

Bearing in mind the drawbacks of any information gathered ex-post and requiring recalls, the information collected from employers and applicants is very rich in the UK surveys. Table 2 lists the variables that we use in our multivariate analysis: characteristics of the employee -before and after the judicial process-, characteristics of the firm, the representative, the settlement offers, the costs of litigation, and the amount awarded are provided at a detailed level. Reasons for decisions made during the process such as reasons for not being represented, for withdrawing or for rejecting settlement are given. Information is also given on the way the dismissal was handled — with or without a formal meeting or a written notification, or on the presence of a human resource department or unions in the workplace- which could help us to understand the bargaining process between employer and employee. Ex-post subjective expectations about the outcome of the case are also available and can be used as a proxy for the quality of the case perceived by the relevant party. As the cases are not matched, some of the information gathered on the employers and the employees is richer and more concise in their respective surveys. However, when possible we give priority to the size of our samples and restrict ourselves to the variables present simultaneously in the 1998 and 2003 waves and in the employee and employer surveys.

Workers and firms report that they were not represented in a large proportion of cases. Twenty five percent of firms take a lawyer against eighteen percent of workers. For workers, a majority of cases go to a full hearing without any representation (55 percent, see table 3). Firms and workers can obtain legal help through other means than hiring a lawyer. A union member, a workmate, or an administrative officer can help the worker with her case. Similarly, a firm can find guidance through an employer's association or an in-house lawyer. We assume that the game of legal representation consists only of choosing whether or not to pay for legal expertise; other sources of legal help are assumed to be free. Of course, it could be claimed that part of the cost of union or federation membership, or part of the pay of an in-house lawyer, correspond to the potential use of legal expertise when an unfair dismissal is brought to trial. But our data do not allow us to assess the cost of this service. Seven percent of workers are represented by a union member, and only five percent of employers are represented by an employer's association.

Note that when reaching the trial stage the respondent reports her legal expenditure and the characteristics of the representation of the other side. Since incurring legal expenses is at the heart of the game of legal representation, we classify as "represented" the respondent that incurs legal 
expenses ${ }^{7}$. The most common case is the one for which neither of the parties is represented at trial (50 percent) followed by the case for which the firm uses a lawyer and the worker does not (26 percent) (see Table 4).

Legal fees are the "total costs personally paid" by the worker or "by the organization" net of the part potentially covered by a trade union or a legal insurance or legal aid or any third party. Assuming the risk-neutrality of both parties, for each party and each case $((\mathrm{L}, \mathrm{L}),(\mathrm{L}, \mathrm{NL}),(\mathrm{NL}, \mathrm{L}),(\mathrm{NL}, \mathrm{NL}))$ we write the pay-off as: $\Pi_{i}=A_{i}-C_{i}$ where $A_{i}$ is the award and $C_{i}$ the legal cost, $i=w$ (worker) or $f$ (firm). The "American" rule of allocation of legal costs prevails in the vast majority of cases (see below). Apart from litigation costs, the worker stands to gain what the firm loses and $A_{w}=-A_{f}$. In Table 6 we report the ex-post gains observed in the raw data for the firms and the workers. The worker is betteroff not hiring a lawyer: when the firm is represented her pay-off is higher and when the firm is not represented she gets a lower, albeit not significantly different, pay-off. The firm substantially decreases the worker's gain by hiring a lawyer especially when the worker is represented, but this decrease is smaller than the additional legal costs the firm incurs. The firm is better off not being represented, and the (NL,NL) is a Nash equilibrium. In this equilibrium, the pay-off is higher than in the $(\mathrm{L}, \mathrm{L})$ case, and we cannot conclude using raw data that there is a prisoner's dilemma.

The equilibrium potentially arising from the computation of the payoff matrix might be distorted in some cases. Contingent-fee arrangements might exist between the parties and their lawyers. These arrangements stipulate that in the event of a victory the lawyer will earn a predetermined percentage of the award and in the event of a defeat he will earn nothing more than a fixed sum, which may be nil. Hence a "no win, no fee" arrangement destroys the possibility of a prisoner dilemma since taking a lawyer is always a dominant strategy. These types of contracts for unfair dismissals are rare. Only three firms that reached the trial stage reported this kind of arrangement in the 1998 wave; the question was not asked of the firms in the 2003 surveys. Twenty-three workers in 1998 and 56 workers in 2003 acknowledge having used this "contingent-fee" arrangement, that is, seven and twenty percent, respectively, of the workers that have been represented by a lawyer at trial. We discard these cases from our analysis as their incentive structure differs from our problem statement ${ }^{8}$.

In the United Kingdom, a tribunal may require the losing party to pay the legal expenses of the winning side -without an assessment of costs- if it finds that the case or defence was "misconceived,

\footnotetext{
${ }^{7}$ When computing the pay-off matrix, we consider other definitions of representation to check the robustness of our results.

${ }^{8}$ According to SETA 2003 data, 50 percent of these contingent-fee cases imply that the worker still has to pay something in the event of a defeat.
} 
vexatious, and/or had no reasonable chance of success". ${ }^{9}$ The prisoner' dilemma is less binding for a worker who thinks that she has such a high quality case that she does not care about litigation costs, since she is sure of getting her money back. At the same time, if the case is of very high quality, it should not be difficult for the party to convince the other side that a settlement is preferable, and these cases should not end up in the pool of adjudicated cases. Thirteen percent of workers and eleven percent of firms reaching the trial stage asked for their costs to be awarded and six and three percent, respectively, have been reimbursed from their legal expenses. We conducted our analysis with and without these cases and did not find significant differences.

Turning to the relationship between representation and trial outcome, sample t-tests on UK data show that using a lawyer gives a significantly higher success probability for the firm, whether or not the worker is represented. In contrast to the studies mentioned in our introduction, we find a significant difference in outcomes between the cases in which both parties are represented and the cases in which neither of the parties is represented: the worker's victory rate is higher when neither of the parties are represented than when both parties are represented (see Table 5).

\section{The French case}

The French labour courts are mainly administered by the "Prud'hommes" (industrial tribunals), which is the relevant jurisdiction for all labour disputes arising at the individual level in France. The judges in the Prudhommes are not professional judges and are seen as performing a public duty. Each labour court comprises judges representing employers and judges representing employees in equal number. These judges are elected by employees, business owners and managers every five years from lists established by unions and federations. If an equal number of judges are for and against the worker, there is a tie ("solution de départage"). In this case, a single professional judge decides the outcome of the trial. This occurs in less of 10 percent of the cases.

Our data come from administrative records made at the level of each Prud'homme and collected by the statistical department of the French Ministry of Justice. Their primary goal is to monitor the labour courts' activities, with an emphasis on speed of treatment. The data source is exhaustive for the period 1990 to 2004. It includes approximately two million individual cases, among which little more than one million have been brought to trial. Irrespective of the outcome of the case, the characteristics of the representation of both parties are included. However, we restrict ourselves to cases reaching trial to maintain comparability with the UK case. The French data include a rough indicator of firm size (less or more than 10 employees), the industry of the firm, the age and sex of the plaintiff, the jurisdiction

\footnotetext{
${ }^{9}$ A similar rule exists in France, but an assessment of the costs is made by the judge.
} 
of the case, the eligibility for judicial assistance benefits, the right to appeal against the court's decision (if the award at stake is larger than a given threshold: about EUR 5,000 in 2006).

In contrast to the UK, firms and workers are often represented by a lawyer in France (respectively (72 percent and 62 percent of the cases). As a consequence, a large proportion of French cases lead to a battle between two lawyers (46 percent, see Table 4). The more regulated French labour market might increase the complexity of the labour laws and hence make more necessary the use of legal expertise. As underlined by Blanchard and Philippon (2004) and Algan and Cahuc (2007), due to the history of the political and social movement, French industrial relations in the recent past might have been less smooth than in the UK. As in the UK, firms and workers can obtain legal help through other means than hiring a lawyer. The proportion of workers represented by a union member is much higher (23 percent) but the proportion of employers represented by an employer's association is similar (4 percent, see Table 3).

Cases in which a firm is represented result in significantly lower victory rates for workers. In contrast, when workers are represented, this does not appear to have a noticeable impact on the victory rates for workers (see Table 5).

\section{Pay-off Matrix of the Game}

\section{Legal Representation and Probability of Victory for Workers}

The choice of hiring a lawyer is likely to depend on the quality of the case as perceived by both parties. Theoretical models of litigation stress differences in expectations (see Priest and Klein (1984)) or informational asymmetry (see Bebchuk (1984)) regarding this quality and make predictions on win, trial, or settlement rates. In these models, litigation costs have no influence on the judicial process other than to give the parties an incentive to settle or to litigate: the legal expenses do not impact the probability of winning or the size of the award and only correspond to entry costs into the litigation process. However, Cooter and Rubinfeld (1989) and Spier and Hay (1998) stress the fact that the plaintiff's litigation costs are endogenous rather exogenous: “the plaintiff's investment choice will reflect both the underlying facts of the case and the beliefs that the plaintiff holds about the future of the case - including those concerning the investments and responses of the defendant". Hirshleifer and Osborne (2002) combine the quality of the case -considered as common knowledge- and the parties' litigation costs as inputs of a litigation success function over which the plaintiff and defendant optimise. Assuming risk-neutral parties, a Nash protocol implies that plaintiff and defendant incur the same level of legal expenses. This level is a quadratic function of the case quality, reaching its peak at the midpoint. Considering a Stackelberg game with the plaintiff as the leader, they show that the side 
with the better case fights harder, and for a high-quality case the defendant concedes. Hence theoretical models show that litigation costs and the quality of the cases are likely to be intermingled.

Unfortunately, except in the noteworthy case of studies using medical malpractices in Florida in the early 1980s (see Farber and White, 1990), the empirical literature on the legal process is plagued by the absence of direct measures of case quality. However, our analysis is limited to individual labour disputes, thus guaranteeing some uniformity across the cases. Moreover, in contrast to the existing literature, the richness of our UK database allows us to include numerous controls that are likely to be related to the quality of the cases. The presence of a union at the workplace and a firm large enough to possess a personnel department, both facilitating access to legal expertise and knowledge in dealing with unfair dismissal cases, are likely to filter out low quality cases. Skill, pay, and industry might also be related to the ability to gauge the quality of cases and to the potential amount awarded that is taken into account by the parties when deciding to invest in legal representation. ${ }^{10}$

We estimate probit models in which the dependent variable is the probability of worker's victory at trial. Our results are consistent with our observations from the raw data. Regarding the French data, restriction tests show that the probability of victory meets some necessary conditions for the pay-off matrix to correspond to a prisoner's dilemma. A lawyer slightly increases the probability of victory irrespective of the legal representation of the other party (see Tables 7 and 8). The reference point is when none of the parties is represented. A lawyer increases the worker's victory rate by 0.04 against represented firms $(-0.04-(-0.08)=0.04)$ and by $0.02(0.02-0)$ against unrepresented firms. A lawyer increases the likelihood of success of the firm by 0.08 against an unrepresented worker and by 0.06 against a represented worker. Given the amount at stake and the legal costs (see below), it would be surprising that these small increases make the hiring of a lawyer profitable. Finally, contrary to what has been shown in the previous empirical literature, the probability of a worker's victory is different under the (L,L) and (NL,NL) cases: on the one hand, the worker is worse off in the (L,L) case, which is consistent with a prisoner dilemma but, on the other hand, a higher probability of victory for the firm can make its investment worthwhile.

In the UK case, a lawyer substantially increases the probability of the firm prevailing irrespective of whether or not the worker is represented. No significant difference is found for the worker. As in the French case, the (L,L) cases display significantly lower probabilities of worker's victory than the (NL,NL) cases, and an assessment of the related costs is necessary to conclude that there is a prisoner's dilemma where (L,L) should be a lower equilibrium outcome than (NL,NL).

\footnotetext{
${ }^{10}$ See Knight and Latreille (2001) who study the gender difference at trial using the 1992 SETA wave and discuss thoroughly the determinants of the case outcome.
} 


\section{Legal Representation and Net Gain}

\section{The French case}

Administrative French data do not contain information on costs or awards. As mentioned above without any assumption on costs- workers are better off when no lawyers are involved than when both parties are represented, since in the former case their probability of victory is higher. Serverin (2000), using a survey of 7,962 cases collected in 1996 among 248 of the 264 French labour courts, estimates the average award asked by the worker at FRF 78,000, e.g. approximately the annual gross minimum wage. The French lawyers we surveyed typically charge a fixed sum of EUR 1,000 for workers plus 18 percent of the potential outcome and a fixed sum of about EUR 8,000 for employers. We tentatively compute the matrix pay-off using the data available in the French case. Using these amounts and the marginal probabilities displayed in Table 7, we compute the payoff matrix (see Table 9). The dominant strategies for both parties would be not to be represented. Another way to see the results is to compute the threshold of litigation costs under which hiring a lawyer would be a dominant strategy. The firm is better off in the (L,L) case than in the (NL,NL) case if legal costs are lower than EUR 955. Hence the firm is also likely to prefer the (NL,NL) case to the (L,L) case.

The worker (firm) must pay less than EUR 320 (EUR 2,900) in lawyer's fees to choose to be represented, irrespective of the other party's choice ${ }^{11}$. These thresholds are far lower than those reported for unfair dismissal cases.

\section{The UK case}

Anecdotal evidence shows that the equilibrium of the game in the French case involves neither party being represented. The UK case is more interesting, since we are able to directly account for the cost of representation in a richer information set. We start by estimating OLS models in which the net gain of the trial is regressed on the legal representation variables and additional controls. As the lawyer's fees are known for the respondent of the questionnaire, we estimate separate regressions for the firms' sample (Net gain =-Award-Legal fees) and the workers' sample (Net gain=Award-Legal fees). The results are (partially) reported in Tables 10 and 11. The parameters associated with legal representation do not differ significantly from zero in the workers' regression. Hiring a lawyer (the "lwlf" and "nlwlf" variables) corresponds to smaller net gains for the firms. $F$ tests show that these gains are significantly lower when the worker is represented (see table 11). (L,L) is dominated by (NL,NL) both for the firm and the worker. These results are summarized in the pay-off matrix in table 12 .

\footnotetext{
${ }^{11}$ These thresholds might actually be lower since the award asked by the worker is likely to be an upper bound for the award actually received. It can be observed that the fixed sum usually paid by the worker in his feecontingent agreement is even larger than the threshold. Lawyers' hourly fees are typically around EUR 225.
} 
Half of all trials result in no award being made. To account for the mass point at zero of the award distribution, we could estimate a Tobit model. However, we suspect that legal representation has a differentiated impact on the probability of prevailing and the amount awarded. For example, in of the case of an unfair dismissal, in addition to a potential compensatory award, a basic award calculated on the basis of the number of weeks of tenure and the weekly salary of the lost job is awarded to the applicant in the event of success. ${ }^{12}$ The decision of the judge as to whether or not to make an award should not be based on these characteristics but on the intrinsic quality of the case ${ }^{13}$. Hence, we model the amount awarded using a double-hurdle model that offers more flexibility than a Tobit-type I model:

$$
\left\{\begin{array}{l}
P(\text { win }=0 \mid X)=1-\Phi(X \gamma) \\
\log (\text { award }) \mid X, \text { award }>0 \sim \operatorname{Normal}\left(X \beta, \sigma^{2}\right)
\end{array}\right.
$$

This implies that:

$$
E(\log (\text { award }) \mid X)=\Phi(X \gamma) \exp \left(X \beta+\sigma^{2} / 2\right)
$$

A selection model à la Heckman identified beyond the functional form by the exclusion of the worker's pay in the selection equation leads us to reject the dependence of the residuals between the "selection" and the "wage" equations. In the following, we assume the residuals to be normal and independent between both equations.

Table 13 shows that the legal representation has a differentiated impact on the probability of worker's victory and on the level of award which justified the use of a double-hurdle model. For instance, (L,L) cases are both related to a larger probability for the firm to prevail and a larger award for the worker in the event of victory. When more is at stake, firms are more likely to choose to be represented and then to win the trial. A likelihood ratio test confirms that the double-hurdle model beats the Tobit model in term of goodness-of-fit. We compute the predicted award under the four cases of legal representation using the full sample. A firm hiring a lawyer does not pay significantly lower awards but a represented worker gains more when facing an unrepresented firm. (see table 14).

To control for observed characteristics the litigation costs reported in the respondent questionnaire, we estimate OLS regressions explaining the legal expenditure by the controls used in the award

\footnotetext{
${ }^{12}$ In the SETA classification, individual labour disputes other than unfair dismissal are: redundancy payment, discrimination, breach of contract, wage contract.

${ }^{13}$ Latreille and Knight (2001) were the first to propose this argument in order to identify with a Tobit-type I model and beyond its functional form the selection bias surrounding the amount awarded to the winning side.
} 
regressions and a dummy equalling one if the other party is represented. ${ }^{14}$ It can be assumed that the amount of litigation costs could have a direct impact on the worker's victory rate. However, they are insignificant when included in equation (1). A represented firm augments the legal expenditure of the workers but a represented worker has no significant impact on the legal expenditure of the firms (see Table 15).

We combined the predicted award from the double-hurdle and the OLS regressions to compute the pay-off matrix. For illustration, the worker's pay-off in the case $(\mathrm{L}, \mathrm{L})$ is computed as followed :

$$
\hat{E}(\text { award } \mid l w l f=1, \text { lwnlf }=0, \text { nlwlf }=0, X)-\hat{E}(\cos t \mid \text { emplawhear }=1, X)
$$

Where $\hat{E}$ is the sample mean of the predicted values.

The results are displayed in Table 16. We compute the standard-deviation of the gains using the deltamethod. Using this standard-deviation we compute the associated t-statistics (see Table 17). No differential impact of representation is found for the workers. By contrast, represented firms show significantly lower pay-offs when the worker is not represented. The firm is better off when neither of the parties is represented rather than when both of them are represented.

\section{Robustness Checks for the UK case}

Treating the specifications of Table 13 and 15 as our baseline, we describe some robustness checks below.

First, we discard insignificant variables and adopt a more parsimonious specification. Using the firm survey, an interesting feature is that, once the legal representation is included, the worker's probability of winning is primarily associated with the jurisdictions and the region of the case. Using the worker survey, in addition to region and jurisdictions, firm size, union density and working time play a role. In both samples, the amount of the award is related to applicant's characteristics such as tenure, pay, gender and skill.

Second, previous results consider only firms opting for an outside lawyer as we assume that the service provided by an in-house lawyer goes beyond working on a single Employment Tribunal case. Nevertheless, our results could be driven by the presence of in-house lawyers performing particularly badly. The SETA 2003 survey shows that $25 \%$ of the legal specialists representing the firms at trial are in-house lawyers but the SETA 1998 survey does not allow for such information to be recovered. We

\footnotetext{
${ }^{14}$ In our baseline specification, costs are null if no lawyer is involved.
} 
restrict our analysis to small workplaces (less than 25 employees) where the presence of a company lawyer is less likely.

Third, we use alternative definitions of legal representation. In the "Classification 2" specification we consider represented only firms and workers that report simultaneously that they have incurred uncovered legal expense and been represented by a lawyer at trial. Hence, in comparison to the baseline, we exclude from the category of being represented those who have paid for legal advice without being represented at the tribunal. In the "Classification 3" specification, we consider represented all those that report that they have been represented at trial. This latter definition of legal representation is not based on the fact that they have incurred legal expenses either during the settlement process or at the trial stage.

Fourth, as awards and expenses show a high level of variability and our sample size is relatively small our results could be driven by outliers. Thus we discard observations for which awards and expenses are in the upper decile of positive values.

Fifth, we try to augment the homogeneity of our data set by only considering cases that have been brought under the "unfair dismissal" jurisdiction discarding "discrimination", "redundancy payment", "breach of contract" and "wage" cases and allowing the observables to control more for the quality of the case.

Finally, we consider separately the 1998 and the 2003 waves to be compositional effect that could be related to a change in the regulation or the legal environment or inflation in legal fees might change the pay-off in being represented or develop alternative sources of representation.

We compare the pay-off matrix obtained from these specifications to our baseline bearing in mind that some of them lead to a significant drop in the sample size (see Table 17). Columns (3), (4) and (5) report t-statistics for testing significant differences in net gains from the different legal configuration.

On the worker side, as in our baseline representation, it makes no difference except when the sample is stripped of outliers and different classifications of representation are considered. In these cases, a represented worker makes additional gains compared to an unrepresented firm.

On the firm side, representation is not worthwhile when the worker is not represented in all specifications but one: small workplaces are not significantly hurt by legal representation. In all specifications the firm remains better off when neither of the parties is represented. 
To summarize, after taking into account legal costs our data are inconsistent with the prisoner's dilemma suggested by Ashenfelter and Bloom (1990) who based their analysis only on probabilities of prevailing. Some of the necessary conditions regarding the probability of victory are met, as in previous studies, in our two data sets (French and UK): hiring a lawyer is associated with a larger probability of victory for the firm, regardless of the decision of the other party. However, a noticeable feature of our results is the small but mostly insignificant impact of lawyers on the worker side, both on the probability of prevailing and on the total pay-off. In contrast, we find that the return to hiring a lawyer for the firm is, on average, negative when the worker is not represented. Hence, from the firm's point of view the dominant strategy would be not to be represented, and the worker would vary between being or not being represented. If the worker chooses the pure strategy of not being represented, the game would result in the high equilibrium.

We have computed the observed pay-off matrix of a two-player game controlling for the observed characteristics of the parties. Concerning the worker, our findings suggest that the game played by the worker and the firm should lead to both parties not being represented. In the case of the UK data, (NL,NL) is indeed the most prevalent case (56 percent). The next section discusses the biases that might surround our estimates and tests some explanations as to why some firms deviate from this equilibrium.

\section{Discussion}

We do not make any causal inference. Halla (2007) uses a propensity score technique to construct a causal analysis of the efficiency of lawyers in divorce cases. This method, like all other matching techniques, accounts for selection in the hiring of a lawyer based on observables and can be approximated by weighted regressions (see Angrist and Pischke, 2009). In this paper, we compute the pay-off matrix controlling for plaintiff and defendant characteristics and unusually rich information on the case. However, we suspect that our results may be biased by a double selection process: the one leading to choose legal representation and the one leading to drop or settle or go to trial. Thus, with respect to their unobserved qualities, the cases in a quarter of legal representation configurations might not represent a random sample of cases that fall under Employment Tribunal jurisdictions. In the following, we test some hypothesis that could explain a non random allocation of the cases across the configurations of representation. For this purpose, we use information from the SETA surveys that we were unable to exploit in our computations of pay-off matrices. 
A lawyer might help to offset the poor quality of a case and no representation could correspond to cases of such high quality that plaintiff and defendant do not feel the need for legal assistance. Under this conjecture, our results would underestimate the beneficial impact of lawyers. In the SETA surveys, workers and firms are asked if they thought that their case was likely to be successful when they filed the case or were notified ${ }^{15}$. We do not know the exact time at which the worker uses a lawyer -if she does- and the filing of the case and her personal assessment of her case might be influenced by a preliminary meeting with a lawyer. Conversely, given the question asked to the employer, it is likely that her own assessment is reported and it is less likely that the optimism occurs because a lawyer has been retained. Firms and workers show a very high level of optimism about their cases $^{16}: 68$ percent of the managers and 73 percent of the workers thought that they were likely to win at the beginning of the process. However, we observe that the preliminary negative assessment on the case made by the party is not positively associated to the hiring of a lawyer, at least for the firm (see table 18). The assessment of the worker is not significantly related to the outcome of the case at trial but the likelihood of taking a lawyer is higher when the worker thinks that her chances are even. The assessment of the firm regarding the case is verified by the outcome at trial but does not seem to explain the decision to use a lawyer (see Table 18). If we interpret at face value the assessment made by the employer on the case as a quality measure, the firm does not hire a lawyer because of the bad quality of the case, and this cannot explain the bad performance of the firms' lawyers at trial.

\section{Lawyer-Client misalignment of interest}

The relationship between lawyer and client can be modelled as a principal-agent problem, and a misalignment could arise. Paid by the hour, a lawyer could lie to her client on the true merit of the case even if it could be argued that a reputation effect might prevent the lawyer from doing so. We cannot trace back the decision by workers and firms either to settle or dismiss after having consulted a lawyer and before filing the case. Nonetheless, the fact that a smaller probability of dropping the case is associated with hiring a lawyer and no significant impact of the lawyers on avoiding trials seem to suggest that the assumption that lawyers filter out low-quality cases before going to a full hearing does not hold (see Table 19).

\footnotetext{
${ }^{15}$ More precisely the SETA 2003 survey asks "When you first put in your Employment Tribunal Application form (or When you first received notification that [APPLICANT] had applied for an employment tribunal) did you think you were likely to be successful, likely to be unsuccessful, or had an even chance? " The answer is coded in 5 categories: Very likely to be successful, Quite likely to be successful, Quite Likely to be unsuccessful, Very likely to be unsuccessful, Or that you had an even chance. In order to match the 1998 questionnaire, we group the "very likely" and the "quite likely successful" categories the same for the "very likely" and "quite likely to be unsuccessful".

${ }^{16}$ This supports strongly the "optimism bias" assumption made in the literature to explain the litigation puzzle.
} 


\section{Pre-trial stage and irreversible investment}

We have restricted our analysis to cases reaching the trial stage, since the information on the representation of both parties is available only for this stage. The prisoner's dilemma - the choice to be represented at a tribunal's full hearing- might arise irrespective of the steps preceding the trial. Nevertheless, it could be claimed that the return to hiring a lawyer obtained during the pre-trial stage might lead to choosing legal representation at trial. For instance, in order to obtain a favourable settlement outcome, one party might use the service of a lawyer. In the event of a bargaining failure, the party continues to be represented, since most of the investment in the case has already been made beforehand. It might be inefficient to use a lawyer during the bargaining process and then decide to lose her knowledge of the case and her ability to present a case for the full hearing in front of the tribunal: an expected positive impact of the lawyer on settlement could explain her presence at trial. The firms' 2003 SETA shows that, among firms reaching trials, sixteen percent switch from no representation before the trial to representation by an outside lawyer at trial. Seventy four percent of the firms that hire a lawyer before the trial are also represented by a lawyer at the tribunal hearing. Hence, the switch between no representation and representation by a lawyer at the time of the trial is relatively rare. We ignore the characteristics of the party facing the respondent during the settlement process and cannot compute a pay-off matrix of the game of legal representation. However, we can measure the impact of a lawyer on the settlement outcome and this impact might explain why a lawyer is retained at trial even if it does not appear worthwhile ex-post. The UK data show that a vast majority of the cases (almost 80 percent) are withdrawn or settled. Concerning the firm, we have seen that a lawyer is associated with a lower probability of cases being withdrawn but has no significant impact on the likelihood of them being settled or going to trial.

Turning to the financial impact of a lawyer, and restricting ourselves to cases that have been settled dismissed or withdrawn, we estimate again a double-hurdle model for the settlement amount awarded by the firm to the worker on the one hand and the probability that the settlement might be positive on the other hand (see Table 20). ${ }^{17}$ We cannot test whether the representation of the firm is related to the representation of the worker during the pre-trial stage. We include a dummy equalling one if a lawyer represents the party. A lawyer representing the firm is associated with a larger settlement amount and a higher probability of settling (see Table 20, columns (2)). We observe a similar result on the employee side. Using these estimates, we compute the pay-off of the pre-trial stage for the firms and workers that do not reach the trial stage when they use or do not use a lawyer (see Table 21). Firms are not better-off using a lawyer during the pre-trial bargaining but lawyers appear to help workers to get

\footnotetext{
${ }^{17}$ The settlement amount awarded by the firm to the worker might be zero in the event the case is dismissed.
} 
more. We conclude that the impact of the firm lawyer during the pre-trial stage does not seem to justify her presence at the tribunal.

\section{Beyond the financial costs of the judicial process}

The costs related to an unfair dismissal process might go beyond the payment of the award and the litigation cost. The firm might want to send its current employees a signal of being tough on shirking and lack of performance not only by firing shirkers but also by refusing them any compensation and going to trial. In the 2003 SETA surveys, the employer is asked whether, apart from any financial costs involved, the case has any other negative effects on the organisation. Forty percent of employers having reached the trial stage recognise that they have incurred non-financial costs. As it is an open question in both waves, the wording of the categories differs between the 1998 and the 2003 waves. Among those reporting non-financial costs and having reached the trial, an increase in staff stress, a bad reputation and damaged workplace relations are the most often reported in 1998 (respectively 65 percent, 31 percent and 21 percent). In 2003, among the thirty-eight percent of managers reporting non financial costs, thirty-eight percent mention an increase in the level of stress and an interruption in business, twenty-five percent low staff morale, and nine percent bad publicity. Only three percent of the managers mention the fear of a contagion effect, e.g. the case could push other people to make claims. Given these numbers, it is hard to conjecture that employers would flex their muscles by hiring a lawyer only for the purpose of threatening their current staff with filing a case. However, probit models estimated on employers' data both on the total number of the case and on the cases having reached trial show a significant relationship between legal representation and the reporting of nonfinancial costs. Reporting non-financial costs results in a significant increase of 0.1 in the probability of hiring a lawyer, irrespective of whether the firm reaches the trial stage. (see table 22).

\section{Conclusion}

As in the previous empirical literature, but exploiting a richer data set, we find that hiring a lawyer increases the probability of victory of the defendant at trial. By contrast, a small or even insignificant impact is seen on the plaintiff side. Moreover, lawyers do not neutralize each other when retained on both sides of a dispute, and legal representation is less beneficial to the plaintiff when both parties are represented than when neither of them uses a lawyer. This invalidates the presence of a prisoner's dilemma in the game of legal representation. When we consider the cost of legal representation which has not been formally done in prior empirical work, we observe that the return to hiring a lawyer is negative for the defendant. The plaintiff's pay-off does not differ according to whether she is 
represented or not. In our context, we could interpret this last result as suggesting that workers are good at making the trade-off between the quality of the case and the necessity of legal representation.

At least in our UK data, for which we are able to compute pay-offs, the game of representation leads to a high equilibrium in a majority of the cases. However, we fall short of explanations for the negative return to hiring a lawyer for the firm. Selection bias on the quality of the cases, misalignment of interests between the firm and the lawyer, ex-ante positive returns during the pre-trial stage, or reputation effects do not seem to drive our results. Non financial costs might. A targeted survey on the reasons for the choice of legal representation as well as a detailed timing of this choice could be very useful for further investigation. 


\section{References}

Angrist J. and J.S. Pischke (2009), "Mostly Harmless econometrics: an empiricist's companion", Princeton University Press, Princeton (NJ), USA.

Ashenfelter, O. and D. Bloom (1990), "Lawyers as Agents of the Devil in a Prisoner's Dilemma Game", NBER Working Papers 4447, National Bureau of Economic Research, Cambridge, Massachusetts.

Ashenfelter, O. and G. Dahl (2005), "Bargaining and the Role of Expert Agents: An Empirical Study of Final Offer Arbitration", NBER Working Papers 11189, National Bureau of Economic Research, Cambridge, Massachusetts.

Bebchuk L. A., 1984. "Litigation and Settlement under Imperfect Information". RAND Journal of Economics, The RAND Corporation, vol. 15(3), pages 404-415, Autumn.

Bjorn, P., and Q. Vuong (1984), "Simultaneous models for dummy endogenous variables: a game theoretic formulation with an application to household labor force participation", Working paper, California Institute of Technology.

Bjorn, P., and Q. Vuong (1985), "Econometric modelling of a Stackelberg game with an application to household labor force participation", Working paper, California Institute of Technology.

Blanchard, O. and T. Philippon (2004), "The Quality of Labor Relations and Unemployment”, NBER Working Paper No. W10590.

Blanchard O. and J. Tirole (2004), "Protection de l'emploi et procédures de licenciement”,Rapport du CAE n.44.

Block, R. N., and J. Stieber (1987) . "The Impact of Attorneys and Arbitrators on Arbitration Awards." Industrial and Labor Relations Review 40 July: 543-55.

Bresnahan, T. F., and P. C. Reiss (1991), "Empirical models of discrete games", Journal of Econometrics, 48, 57-81.

Cahuc P. and Y. Algan, (2007) "La société de défiance: comment le modèle social s'autodétruit", Editions de la Rue d’Ulm, collection CEPREMAP.

Cooter, Robert D. and Daniel L. Rubinfeld (1989), 'Economic Analysis of Legal Disputes and Their Resolution', Journal of Economic Literature 27(3), 1067-1097.

Cragg J.( 1971), «Some Statistical Models for Limited Dependent Variables with Application to the Demand for Durable Goods », Econometrica, n³9, pp.829-844.

Department of Trade and Industry. Employment Market Analysis and Research and BMRB. Social Research, Survey of Employment Tribunal Applications, 2003 [computer file]. Colchester, Essex: UK Data Archive [distributor], October 2004. SN: 5022.

Department of Trade and Industry. Employment Market Analysis and Research and National Centre for Social Research, Survey of Employment Tribunal Applications, 1998 [computer file]. Colchester, Essex: UK Data Archive [distributor], April 2004. SN: 4894. 
Farber H.S. and M.J. White, 1991, "Medical Malpractice: An Empirical Examination of the Litigation Process," RAND Journal of Economics 22, no. 2: 199-217.

Halla M. (2007) "Divorce and the Excess Burden of Lawyers", Working Paper No. 0713, Department of Economics, Johannes Kepler University of Linz, July.

Heckman, J.J. (1978), "Dummy edogenous variables in a simultaneous equation system", Econometrica, 46, 931-60.

Hirshleifer, J., Osborne, E., (2001). Truth, effort, and the legal battle. Public Choice 108, 169-195.

Kooreman, Peter, (1994). "Estimation of Econometric Models of Some Discrete Games," Journal of Applied Econometrics, John Wiley \& Sons, Ltd., vol. 9(3), pages 255-68, July-Sept.

McDowell, A. (2003) "From the help desk: hurdle models," The Stata Journal, 3:2 (178-184).

Priest, G. and B. Klein (1984)."The selection of disputes for litigation", Journal of Legal Studies, 13:155 .

Serverin E. (2002), «Les litiges du travail au temps du jugement prud'homal», Revue nationale des Barreaux, n 66/67, p. 67-167.

Spier, K. \& B. L. Hay, (1998). "Settlement of Litigation" in The New Palgrave Dictionary of Economics and the Law 442 , Peter Newman ed., MacMillan Reference Limited.

Wagar T.H. (1994), "The effect of lawyers on non-discipline/discharge arbitration decisions, Journal of Labor Research, Volume 15, Number 3 / September : 283-93.

Wilde Joachim, (2000). "Identification of multiple equation probit models with endogenous dummy regressors", Economics Letters, Volume 69, Issue 3, , December, Pages 309-312. 
Table 1: Variables description: UK data

\begin{tabular}{|c|c|}
\hline Variable & Description \\
\hline Costrule & Dummy equal 1 if case of 2003 wave \\
\hline \multicolumn{2}{|l|}{ Economic Activity } \\
\hline VAT & Regional VAT deregistration rate \\
\hline $\mathrm{UE}$ & Regional Unemployment \\
\hline \multicolumn{2}{|l|}{ Case Characteristics } \\
\hline settle & Case outcome (dummy equal 1 if case settled) \\
\hline withdw & Case outcome (dummy equal 1 if case withdrawn) \\
\hline dismets & Case outcome (dummy equal 1 if case dismissed) \\
\hline trial & Case outcome (dummy equal 1 if case reach a full hearing) \\
\hline appwin & Case outcome (dummy equal 1 if applicant win at trial) \\
\hline chanceplus & Perceived likelihood of success (dummy equal to 1 if likely to win) \\
\hline chanceeven & Perceived likelihood of success (dummy equal to 1 if even chance) \\
\hline chanceless & Perceived likelihood of success (dummy equal to 1 if likely to lose) \\
\hline unfair & Main jurisdiction (dummy equal 1 if unfair dismissal) \\
\hline breach & Main jurisdiction (dummy equal 1 if breach of contract) \\
\hline wages & Main jurisdiction (dummy equal 1 if wage contract) \\
\hline discri & Main jurisdiction (dummy equal 1 if any discrimination) \\
\hline redund & Main jurisdiction (dummy equal 1 if redundancy payment) \\
\hline writproc & $\begin{array}{l}\text { Written Procedure (dummy, equal } 1 \text { if applicant issued with written statement stating terms and conditions of } \\
\text { employment) }\end{array}$ \\
\hline warningdes & Warning before dismissal (dummy equal 1 if the employer warned the applicant before dismissal) \\
\hline discus & $\begin{array}{l}\text { Discussion before filing (dummy equal } 1 \text { if the issue was discussed by employer with applicant before } \\
\text { application }\end{array}$ \\
\hline \multicolumn{2}{|r|}{ PT } \\
\hline age & Age \\
\hline female & Female \\
\hline ann_pay & Annual Pay (base year 1997) \\
\hline bpay1 & Annual Pay (dummy, equal 1 if less than 10,000 pounds) \\
\hline bpay2 & Annual Pay (dummy, equal 1 if between 10,000 and 15,000 pounds) \\
\hline bpay3 & Annual Pay (dummy, equal 1 if between 15,000 and 20,000 pounds) \\
\hline bpay4 & Annual Pay (dummy, equal 1 if more than 20,000 pounds) \\
\hline tenure & Tenure in years \\
\hline btenure 1 & Tenure (dummy, equal 1 if less than 1 year) \\
\hline btenure2 & Tenure (dummy, equal 1 if between 1 and 3 years) \\
\hline btenure 3 & Tenure (dummy, equal 1 if between 3 and 7 years) \\
\hline btenure4 & Tenure (dummy, equal 1 if more than 7 years) \\
\hline managerprof & Occupation (dummy, equal 1 if Managerial/Professional occupation) \\
\hline lowskill & Occupation (dummy, equal 1 if Elementary Occupation or Process, Plant, and Machine Operatives occupation) \\
\hline partime & Employment Status (dummy, equal 1 if employed part time) \\
\hline union & Union (dummy, equal 1 if union present at the workplace) \\
\hline unionmemb & Union Member (dummy, equal 1 if applicant union member) \\
\hline currempl & Current Employment Status (dummy, equal 1 if currently employed) \\
\hline moremoneynewjob & Current Employment Status (dummy, equal 1 if applicant earns more money in her new job) \\
\hline samemoneynewjob & Current Employment Status (dummy, equal 1 if applicant earns same amount of money in her new job) \\
\hline lessmoneynewjob & Current Employment Status (dummy, equal 1 if applicant earns less money in her new job) \\
\hline \multicolumn{2}{|l|}{ Firm Characteristics } \\
\hline asizew1 & Workplace size (dummy, equal 1 if less than 25 ) \\
\hline asizew2 & Workplace size (dummy, equal 1 if bewteen 25 and 49 ) \\
\hline asizew3 & Workplace size (dummy, equal 1 if bewteen 50 and 250) \\
\hline asizew4 & Workplace size (dummy, equal 1 if more than 250 ) \\
\hline public & Public/Private/Non Profit sector statys (dummy, equal 1 if public sector) \\
\hline private & Public/Private/Non Profit sector statys (dummy, equal 1 if private sector) \\
\hline nonprofit & Public/Private/Non Profit sector statys (dummy, equal 1 if non profit sector) \\
\hline sicgp1 & Industry (dummy equal 1 if agriculture and fishing) \\
\hline sicgp2 & Industry (dummy equal 1 if mining and utilities) \\
\hline sicgp3 & Industry (dummy equal 1 if manufacturing) \\
\hline sicgp4 & Industry (dummy equal 1 if construction) \\
\hline sicgp5 & Industry (dummy equal 1 if whole and retail) \\
\hline sicgp6 & Industry (dummy equal 1 if hotels and Rest.) \\
\hline sicgp7 & Industry (dummy equal 1 if Transports, Comm. And Utils) \\
\hline sicgp8 & Industry (dummy equal 1 if finance) \\
\hline sicgp9 & Industry (dummy equal 1 if other services and public administration) \\
\hline ea & Firm is member of employers association (dummy equal 1 if member) \\
\hline nbcases 0 & Previous Experience with ET (dummy equal 1 if no experience) \\
\hline nbcases 1 & Previous Experience with ET (dummy equal 1 if at least one case) \\
\hline
\end{tabular}


Table 1: Variables description: UK data (Continued)

\begin{tabular}{cl}
\hline \hline Variable & \multicolumn{1}{c}{ Description } \\
\hline Representation,Cost and Award: & Representation at hearing (dummy equal 1 if lawyer, solicitor or barrister represented applicant) \\
lawhear & Representation at hearing (dummy equal 1 if outside lawyer, solicitor or barrister represented employer) \\
emplawhear & Dummy equal 1 if lawyer and firm both represented by a lawyer \\
lwlf & Dummy equal 1 if the worker is represented by a lawyer but the firm is not \\
lwnlf & Dummy equal 1 if the worker is not represented by a lawyer but the firm is \\
nlwlf & Monetary Settlement (if any) \\
settlemoney & Award at Trial if any \\
award & Legal fees personally paid (if any) \\
legalfee &
\end{tabular}

Table 2: Variables description: French data

\begin{tabular}{|c|c|}
\hline Variable & Description \\
\hline \multicolumn{2}{|l|}{ Economic Activity } \\
\hline UE & Regional Unemployment \\
\hline \multicolumn{2}{|l|}{ Case Characteristics } \\
\hline win & Case outcome (dummy equal 1 if applicant win at trial) \\
\hline unfair & Main jurisdiction (dummy equal 1 if unfair dismissal) \\
\hline breach & Main jurisdiction (dummy equal 1 if breach of contract) \\
\hline wages & Main jurisdiction (dummy equal 1 if wage contract) \\
\hline discri & Main jurisdiction (dummy equal 1 if any discrimination) \\
\hline redund & Main jurisdiction (dummy equal 1 if redundancy payment) \\
\hline \multicolumn{2}{|c|}{ Applicant Characteristics } \\
\hline age & Age \\
\hline female & Female \\
\hline managerprof & Occupation (dummy, equal 1 if workers cases brought to the court dedicated to Managerial occupation) \\
\hline judicial & dummy, equal 1 if the worker is eligible for judicial assistance benefits \\
\hline appeal & dummy, equal 1 if the worker can appeal the decision \\
\hline \multicolumn{2}{|l|}{ Firm Characteristics } \\
\hline Asizew & Workplace size (dummy, equal 1 if less than 10) \\
\hline sicgp1 & Industry (dummy equal 1 if agriculture and fishing) \\
\hline sicgp2 & Industry (dummy equal 1 if mining and utilities) \\
\hline sicgp3 & Industry (dummy equal 1 if manufacturing) \\
\hline sicgp4 & Industry (dummy equal 1 if construction) \\
\hline sicgp5 & Industry (dummy equal 1 if whole and retail) \\
\hline sicgp6 & Industry (dummy equal 1 if hotels and Rest.) \\
\hline sicgp7 & Industry (dummy equal 1 if Transports, Comm. And Utils) \\
\hline sicgp8 & Industry (dummy equal 1 if finance) \\
\hline sicgp9 & Industry (dummy equal 1 if other services and public administration) \\
\hline $\mathrm{Ea}$ & Firm is member of employers association (dummy equal 1 if member) \\
\hline Nbcases0 & Previous Experience with ET (dummy equal 1 if no experience) \\
\hline Nbcases 1 & Previous Experience with ET (dummy equal 1 if at least one case) \\
\hline \multicolumn{2}{|c|}{ Representation, Cost and Award: } \\
\hline lawhear & Representation at hearing (dummy equal 1 if lawyer, solicitor or barrister represented applicant) \\
\hline emplawhear & Representation at hearing (dummy equal 1 if outside lawyer, solicitor or barrister represented employer) \\
\hline lwlf & Dummy equal 1 if lawyer and firm both represented by a lawyer \\
\hline lwnlf & Dummy equal 1 if the worker is represented by a lawyer but the firm is not \\
\hline nlwlf & Dummy equal 1 if the worker is not represented by a lawyer but the firm is \\
\hline Nlwnlf & Dummy equal 1 if neither the worker nor the firm are represented \\
\hline
\end{tabular}


Table 3: Legal Representation at Trial

\begin{tabular}{ccc|cc}
\hline \hline & \multicolumn{2}{c|}{ UK data set } & \multicolumn{2}{c}{ French data set } \\
\hline \hline Representation & Worker & Firm & Worker & Firm \\
\hline None & 0.55 & 0.32 & 0.13 & 0.17 \\
Lawyer & 0.18 & 0.25 & 0.62 & 0.72 \\
Union/Employers' association & 0.07 & 0.05 & 0.23 & 0.04 \\
Others & 0.20 & 0.39 & 0.02 & 0.07 \\
\hline Observations & 826 & 698 & $1,135,852$ & $1,125,551$ \\
\hline \hline
\end{tabular}

Notes: Proportion of workers and firms by types of legal representation such as reported by the respondent. "Others" might include family/friends, workmates, civil servants, human resources specialist, etc.

Source: SETA surveys of 1998 and 2003 and Prud'hommes data from French Ministry of Justice. Observations: $1,123,598$ French cases and 1,254 UK cases.

Table 4: Party's representation

UK data set :

\begin{tabular}{lccc} 
& & \multicolumn{2}{c}{ Defendant uses: } \\
& & A lawyer & No Lawyer \\
Plaintiff uses: & A lawyer & .13 & .11 \\
& No Lawyer & .26 & .50
\end{tabular}

French data set :

Defendant uses:

\begin{tabular}{lccc} 
& & A lawyer & No Lawyer \\
Plaintiff uses: & A lawyer & .46 & .14 \\
& No Lawyer & .24 & .16 \\
\hline
\end{tabular}

Notes: in the UK case, the definition of legal representation is based on the amount of legal expenses for the respondent and the characteristic of the legal representation of the other side as reported by the respondent.

Source: SETA surveys of 1998 and 2003 and Prud'hommes data from French Ministry of Justice. Observations: $1,123,598$ French cases and 1,254 UK cases.

Table 5: Worker's victory at trial and representation

UK data set :

\begin{tabular}{|c|c|c|c|}
\hline & & & \\
\hline & & A lawyer & No Lawyer \\
\hline & A lawyer & $.32(.04)$ & $.57(.05)$ \\
\hline Prainuin uses: & No Lawyer & $.36(.03)$ & $.63(.02)$ \\
\hline
\end{tabular}

French data set :

Defendant uses:

Plaintiff uses:

$\begin{array}{cc}\text { A lawyer } & .74(.004) \\ \text { No Lawyer } & .71(.003)\end{array}$

$\begin{array}{lc}\text { A lawyer } & \text { No Lawyer } \\ .74(.004) & .81(.004) \\ .71(.003) & .80(.002)\end{array}$

Notes: in the UK case, the definition of legal representation is based on the amount of legal expenses for the respondent and the characteristic of the legal representation of the other side as reported by the respondent.

Source: SETA surveys of 1998 and 2003 and Prud'hommes data from French Ministry of Justice. Observations: 1,123,598 French cases and 1,249 UK cases. 
Table 6: Pay-off matrix (UK data)

\begin{tabular}{|c|c|c|c|}
\hline & & \multicolumn{2}{|c|}{ Defendant uses: } \\
\hline \multirow{3}{*}{ Plaintiff uses: } & & A lawyer & No Lawyer \\
\hline & A lawyer & 387 (934),-7337 (1185) & $2174(721),-4824(583)$ \\
\hline & No Lawyer & $1691(503),-2298(660)$ & $1842(197),-856(161)$ \\
\hline
\end{tabular}

Notes: The mean of the net gain is computed on the samples of workers and firms, e.g. 648 workers and 554 firms. Standard deviations are between parentheses.

Source: SETA surveys of 1998 and 2003.

\section{Table 7: Marginal Probabilities from Probit Regressions on the probability of worker's victory at trial}

\begin{tabular}{ccc}
\hline \hline & UK data set & French data set \\
\hline \hline Variable & Marginal probability* & Marginal probability ** \\
\hline Lwlf & $-.17(.05)$ & $-.04(.006)$ \\
Lwnlf & $.04(.05)$ & $.02(.006)$ \\
Nlwlf & $-.15(.04)$ & $-.08(.005)$ \\
\hline \hline
\end{tabular}

Notes : *The marginal probability is computed from a probit regression of the probability of worker's victory on legal representation characteristics and controls $X$. Reference is both parties not being represented ("nlwnlf"). At nlwnlf $=1$, the sample mean of predicted probabilities is .57 . For example, it is reduced by .17 when the sample mean of predicted probabilities is computed at lwlf $=1 . X$ include: 2003 year dummy, jurisdictions, union presence at the workplace, local unemployment rate, gender, skills, pay, tenure, age, firm size, sector, industry,region dummies. Observations: 1,363. SETA samples weights are used.

** The marginal probability is computed from a probit regression of the probability of worker's victory on legal representation characteristics and controls $X$. At nlwnlf $=1$, the sample mean of predicted probabilities is $.78 . X$ include: year dummies, jurisdictions, local unemployment rate, gender, age, firm size, sector , industry, region dummies. Observations: $1,164,950$

Sources: SETA surveys of 1998 and 2003, Prudhommes data from French Ministry of Justice.

Table 8: Wald Tests from Probit Regressions on the probability of worker's victory at trial

\begin{tabular}{|c|c|c|}
\hline & $\overline{~ U K \text { data set }}$ & French data set \\
\hline Test & $P$-value* & $P$-value $* *$ \\
\hline \multicolumn{3}{|l|}{ Worker's strategy } \\
\hline$l w l f=n l w l f$ & 0.79 & 0.0 \\
\hline lwnlf $=$ nlwnlf & 0.36 & 0.0 \\
\hline \multicolumn{3}{|l|}{ Firm's strategy } \\
\hline$l w l f=l w n l f$ & 0.02 & 0.0 \\
\hline nlwlf $=$ nlwnlf & 0.00 & 0.0 \\
\hline$(L, L)$ vs $(N L, N L)$ & 0.00 & 0.0 \\
\hline
\end{tabular}

$\overline{\text { Notes: *P-value from wald tests of equality of parameters from a probit regression of the probability of worker's }}$ victory on legal representation characteristics (reference=nlwnlf) and controls $X . X$ include: 2003 year dummy, jurisdictions, union presence at the workplace, local unemployment rate, gender, skills, pay, tenure,age, firm size, sector, industry, region dummies. Observations: 1,363. SETA samples weights are used.

**P-value from wald tests of equality of parameters from a probit regression of the probability of worker's victory on legal representation characteristics (reference=nlwnlf) and controls. $X$ include: year dummies, jurisdictions, local unemployment rate, gender, age, firm size, sector, industry, region dummies. Observations: $1,164,950$

Sources: Prud'hommes data from French Ministry of Justice. SETA surveys of 1998 and 2003. 
Table 9: Estimates of the pay-off matrix for French data using anecdotal evidence on litigation costs

\begin{tabular}{cccc}
\hline & & Firm uses: & \\
& & A lawyer & No Lawyer \\
Worker uses: & A lawyer & $6980,-17731$ & $9297,-12556$ \\
& No Lawyer & $8476,-16475$ & $12242,-12242$ \\
\hline \hline
\end{tabular}

Notes: Expected gains are computed as $\Pi_{i}=p J_{i}-C_{i}$ where $p$ is the predicted probability computed from a probit regression ran on Prud'hommes data from French Ministry of Justice. Controls include: year dummies, jurisdictions, local unemployment rate, gender, age, firm size, sector, industry, region dummies. $\mathrm{J}=$ one year of gross minimum wage=EUR 15,696. C=EUR 8,000 cost of hiring a lawyer for the firm. $\mathrm{C}=1000+.18 \% \mathrm{~J}$ euro cost of hiring a lawyer for the worker. J negative when firms' expected gains are considered.

Sources: Prud'hommes data from French Ministry of Justice, Anecdotal evidence on lawyers' fees.

Table 10: Net Gain and Legal Representation: OLS estimates

\begin{tabular}{|c|c|c|}
\hline Sample & Workers & Firms \\
\hline Dependant variable & Net Gain* & Net Gain \\
\hline lwlf & $\begin{array}{l}-2061^{*} \\
(1074)\end{array}$ & $\begin{array}{c}-5925 * * * \\
(782)\end{array}$ \\
\hline lwnlf & $\begin{array}{c}-119.1 \\
(870)\end{array}$ & $\begin{array}{c}-4065 * * * \\
(475)\end{array}$ \\
\hline nlwlf & $\begin{array}{c}-553.9 \\
(572) \\
\end{array}$ & $\begin{array}{c}-680.9 \\
(441) \\
\end{array}$ \\
\hline Observations & $\begin{array}{l}648 \\
\end{array}$ & 554 \\
\hline R-squared & $\begin{array}{c}0.10 \\
\end{array}$ & 0.28 \\
\hline
\end{tabular}

Notes: *Net gain is defined as Award-Cost for the worker and -Award-Cost for the firms.

Robust standard errors in parentheses $* * * \mathrm{p}<0.01, * * \mathrm{p}<0.05, * \mathrm{p}<0.1$. Additional controls : 2003 year dummy, jurisdictions, union presence at the workplace, local unemployment rate, gender, skills, pay, tenure, age, firm size, sector, industry, region dummies. Clustering at the official region level.

Source : SETA surveys of 1998 and 2003. SETA sample weights are used.

Table 11: F Tests from OLS Regressions on the net gains

\begin{tabular}{cc}
\hline \hline Test & P-value* \\
\hline Worker's strategy & 0.1729 \\
lwlf $=$ nlwlf & 0.02 \\
lwnlf $=$ nlwnlf &
\end{tabular}

Firm's strategy

$\begin{array}{ll}l w l f=l w n l f & 0.0402 \\ \text { nlwlf }=\text { nlwnlf } & 0.1540\end{array}$

$(L, L)$ vs $(N L, N L)$

Workers 0.0839

Firms 0.0000

Notes: *P-value from $\mathrm{F}$ tests of equality of parameters from a regression of the net gain on legal representation characteristics (reference=nlwnlf) and controls $X . X$ include: 2003 year dummy, jurisdictions, union presence at the workplace, local unemployment rate, gender, skills, pay, tenure, age, firm size, sector, industry, region dummies Observations: 648 for the workers' regression. 557 for the firms' regression. SETA sample weights are used. Source: SETA surveys of 1998 and 2003 
Table 12: Estimate of the pay-off matrix from the OLS regressions

\begin{tabular}{|c|c|c|c|}
\hline \multirow{2}{*}{\multicolumn{2}{|c|}{ 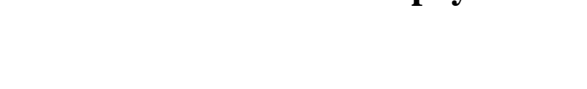 }} & \multicolumn{2}{|c|}{ Firm uses: } \\
\hline & & A lawyer & No Lawyer \\
\hline \multirow[t]{2}{*}{ Worker uses: } & A lawyer & $-15(950),-6909(661)$ & $1927(888),-5049(305)$ \\
\hline & No Lawyer & $1492(193),-1665(215)$ & $2046(128),-984(94)$ \\
\hline
\end{tabular}

Notes: 1249 observations (Standard-deviation in the brackets). Mean sample of predicted values are computed in each representation case $((\mathrm{L}, \mathrm{L}),(\mathrm{L}, \mathrm{NL}),(\mathrm{NL}, \mathrm{L}),(\mathrm{NL}, \mathrm{NL}))$. Standard deviations are computed by delta-method. SETA samples weights are used.

Source: SETA surveys of 1998 and 2003

Table 13: Award and Legal Representation: Double-hurdle estimates

\begin{tabular}{|c|c|c|c|c|c|c|}
\hline \multirow{2}{*}{$\begin{array}{c}\text { Sample } \\
\text { Dependant variable }\end{array}$} & \multicolumn{2}{|c|}{ Firms } & \multicolumn{2}{|c|}{ Workers } & \multicolumn{2}{|c|}{ Whole Sample } \\
\hline & Win & Award (log) & Win & Award(log) & Win & Award (log) \\
\hline Lwlf & $\begin{array}{l}-0.123 \\
(0.20)\end{array}$ & $\begin{array}{l}0.680^{*} \\
(0.31)\end{array}$ & $\begin{array}{c}-0.572 * * * \\
(0.14)\end{array}$ & $\begin{array}{c}0.561 * * \\
(0.21)\end{array}$ & $\begin{array}{c}-0.517 * * * \\
(0.11)\end{array}$ & $\begin{array}{c}0.659 * * * \\
(0.18)\end{array}$ \\
\hline Lwnlf & $\begin{array}{c}0.0488 \\
(0.14)\end{array}$ & $\begin{array}{l}0.463^{*} \\
(0.25)\end{array}$ & $\begin{array}{c}0.0245 \\
(0.16)\end{array}$ & $\begin{array}{l}0.351 \\
(0.21)\end{array}$ & $\begin{array}{c}0.0755 \\
(0.14)\end{array}$ & $\begin{array}{l}0.578 * * * \\
(0.12)\end{array}$ \\
\hline Nlwlf & $\begin{array}{c}-0.509 * * \\
(0.20) \\
\end{array}$ & $\begin{array}{c}0.0469 \\
(0.24) \\
\end{array}$ & $\begin{array}{c}-0.808^{* * *} \\
(0.13) \\
\end{array}$ & $\begin{array}{l}0.287 \\
(0.29) \\
\end{array}$ & $\begin{array}{c}-0.672 * * * \\
(0.080) \\
\end{array}$ & $\begin{array}{c}0.416^{* *} \\
(0.18) \\
\end{array}$ \\
\hline Observations & 576 & 226 & 675 & 432 & 1249 & 658 \\
\hline R-squared & 0.13 & 0.57 & 0.31 & 0.50 & 0.21 & 0.50 \\
\hline
\end{tabular}

Table 14: Estimate of the pay-off (Award) matrix: whole sample

\begin{tabular}{|c|c|c|c|}
\cline { 3 - 4 } \multicolumn{2}{c|}{} & \multicolumn{2}{c|}{ Firm uses: } \\
\cline { 3 - 4 } \multicolumn{2}{c|}{} & A lawyer & No Lawyer \\
\hline \multirow{2}{*}{ Worker uses: } & A lawyer & $2522(644)$ & $2808(354)$ \\
\cline { 2 - 4 } & No Lawyer & $1935(376)$ & $1951(167)$ \\
\hline
\end{tabular}

Notes: 1249 observations (Standard-deviation in the brackets). Mean sample of predicted values are computed in each representation case $((\mathrm{L}, \mathrm{L}),(\mathrm{L}, \mathrm{NL}),(\mathrm{NL}, \mathrm{L}),(\mathrm{NL}, \mathrm{NL}))$. Standard deviations are computed by delta-method. SETA samples weights are used.

Source: SETA surveys of 1998 and 2003 
Table 15: Cost and Legal Representation: OLS estimates

\begin{tabular}{ccc}
\hline \hline \multicolumn{1}{c}{ Sample } & Workers & Firms \\
\hline \hline Dependant variable & Legal costs $(\log )$ & Legal cost $(\log )$ \\
Lawyer (other side) & & \\
& $.92 * *$ & 0.29 \\
Observations & $(0.43)$ & $(0.23)$ \\
\hline \hline R-squared & 130 & 244 \\
\hline \hline
\end{tabular}

Notes: Robust standard errors in parentheses *** $\mathrm{p}<0.01, * * \mathrm{p}<0.05, * \mathrm{p}<0.1$. Additional controls : 2003 year dummy, jurisdictions, union presence at the workplace, local unemployment rate, gender, skills, pay, tenure, age, firm size, sector, industry,region dummies. Clustering at the official region level. SETA samples weights are used.

Source: SETA surveys of 1998 and 2003.

Table 16: Estimate of the pay-off matrix

\begin{tabular}{|c|c|c|c|}
\cline { 3 - 3 } \multicolumn{2}{c|}{} & \multicolumn{2}{c|}{ Firm uses: } \\
\cline { 3 - 4 } \multicolumn{2}{c|}{} & A lawyer & No Lawyer \\
\hline \multirow{2}{*}{ Worker uses: } & A lawyer & $1990(636),-4359(1076)$ & $3136(623),-2496(661)$ \\
\cline { 2 - 4 } & No Lawyer & $1791(499),-3826(603)$ & $2423(224),-1519(373)$ \\
\hline
\end{tabular}

Notes: 1249 observations used to compute the predicted award, 244 observations used to compute the firm's legal costs when positive and 130 observations used to compute the worker's legal cost when positive. (Standard-deviation in the brackets). Mean sample of predicted values are computed in each representation case $((\mathrm{L}, \mathrm{L}),(\mathrm{L}, \mathrm{NL}),(\mathrm{NL}, \mathrm{L}),(\mathrm{NL}, \mathrm{NL}))$. Standard deviations are computed by delta-method. SETA samples weights are used.

Source: SETA surveys of 1998 and 2003. 
Table 17: Estimates of the pay-off matrix: Robustness checks

\begin{tabular}{l|c|c|ccc}
\multirow{2}{*}{ Specifications } & \multicolumn{2}{|c|}{ Matrix Pay-off } & \multicolumn{2}{c}{ Student T Statistic } & \multicolumn{2}{c}{ Observations } \\
Workers/Firms
\end{tabular}

Notes: We compute the estimate of the pay-off matrix for each sub-sample of firms and workers. In each specification, first row, column (1) are the (L,L) case, first row column (2) is the (L,NL) case, second row column (1) is the (NL,L) case and second row column (3) is the (NL,NL) case. In $\mathrm{X}(\mathrm{Z}), \mathrm{Y}(\mathrm{T}), \mathrm{X}$ is the worker's pay-off , $\mathrm{Y}$ is the firm's pay-off. $\mathrm{Z}$ and $\mathrm{T}$ in parenthesis are the corresponding standard deviations. In the first row Columns (3), (4) and (5), we report the Student t statistic comparing for the firm respectively (L,L) vs (L,NL) (NL,L) vs $(\mathrm{NL}, \mathrm{NL})$ and $(\mathrm{L}, \mathrm{L})$ vs $(\mathrm{NL}, \mathrm{NL})$. In the second row Columns (3), (4) and (5), we report the Student $\mathrm{t}$ statistic comparing for the worker respectively $(\mathrm{L}, \mathrm{L})$ vs $(\mathrm{NL}, \mathrm{L})(\mathrm{L}, \mathrm{NL})$ vs $(\mathrm{NL}, \mathrm{NL})$ and $(\mathrm{L}, \mathrm{L})$ vs $(\mathrm{NL}, \mathrm{NL})$

Source: SETA surveys of 1998 and 2003. SETA sample weights are used. In column (6): X,Y means X observations are used in the probit regression and $\mathrm{Y}$ in the truncated regression. The first row is for the regressions on the firms and the second row is for the regression 
Table 18: Legal Representation, Case Outcome at Trial and Assessment on the case at the start of the judicial process: Probit estimates

\begin{tabular}{ccccc}
\hline \hline Sample & \multicolumn{2}{c}{ Firms } & \multicolumn{2}{c}{ Workers } \\
\hline Dependant variable & Lawyer & Worker's victory & Lawyer & Worker's victory \\
\hline \multirow{2}{*}{ chanceeven } & & & & \\
& -0.153 & $0.578^{* * *}$ & $0.167^{* *}$ & 0.123 \\
chanceplus & $(0.099)$ & $(0.19)$ & $(0.071)$ & $(0.24)$ \\
& -0.0871 & $0.654^{* *}$ & -0.0389 & 0.0765 \\
& $(0.064)$ & $(0.27)$ & $(0.073)$ & $(0.26)$ \\
\hline \hline
\end{tabular}

Notes: chanceeven is a dummy variable equalling one if the party thought that she had an even chance of winning the case. Chanceplus is a dummy variable equalling one if the party thought that the case was likely to be successful for the worker. Additional controls: 2003 year dummy, jurisdictions, union presence at the workplace, local unemployment rate, gender, skills, pay, tenure, age, firm size, sector, industry, region dummies. Clustering at the official region level. SETA sample weights are used. Robust standard errors in parentheses $* * * p<0.01$, $* *$ $\mathrm{p}<0.05, * \mathrm{p}<0.1$.

Source: Employer SETA surveys of 1998 and 2003.

Table 19: Marginal Probabilities from a Multinomial Probit Regressions on the outcome of the case and legal representation; Firms' surveys

\begin{tabular}{ccc}
\hline \hline Case outcome & Marginal probability & Predicted value at sample means \\
\hline \hline Withdrawn & $-0.032(0.023)$ & 0.20 \\
Settled & $0.0018(0.022)$ & 0.59 \\
Trial & $0.03(0.026)$ & 0.21 \\
\hline \hline
\end{tabular}

Notes: The marginal probability is computed from a multinomial probit regression for the independent variable: dislawyer (equalling one if an outside lawyer has been hired by the firm). The dependent variable is the outcome of the case (case withdrawn or dismissed, case settled, case adjudicated). Controls include: 2003 year dummy, jurisdictions, union presence at the workplace, local unemployment rate, gender, skills, pay, tenure, age, firm size, sector, industry, region dummies. Clustering at the official region level. Observations: 3,278. SETA sample weights are used.

Source: SETA surveys of 1998 and 2003.

Table 20: Settlement and Legal Representation: Marginal effects from double-hurdle regressions

\begin{tabular}{ccccc}
\hline \hline Sample: & \multicolumn{2}{c}{ Firms } & \multicolumn{2}{c}{ Workers } \\
Dependant variable: & settled & settlement money & settled & Settlement \\
\hline & $(1)$ & $(2)$ & $(3)$ & $(4)$ \\
lawyer & $0.0757^{* * *}$ & $0.402^{* * *}$ & $0.154 * * *$ & $0.617 * * *$ \\
& 0.028 & 0.072 & 0.022 & 0.065 \\
Observations & 2657 & 1555 & 2473 & 1661 \\
\hline \hline
\end{tabular}

Notes: Lawyer is a dummy variable equalling one if a lawyer has been involved in the pre-trial stage and zero otherwise. Settlement money is in log. Cases going to trial are excluded. Marginal probabilities of having undertaken legal expense are reported in columns (1) and (2). Parameters of the second stage linear regressions are reported in columns (2) and (4). Additional controls: 2003 year dummy, jurisdictions, union presence at the workplace, local unemployment rate, gender, skills, pay, tenure, age, firm size, sector, industry, region dummies. Clustering at the official region level. Robust standard errors in parentheses $* * * p<0.01, * * p<0.05, * p<0.1$.

Source: SETA surveys of 1998 and 2003. 
Table 21: Estimates of the pay-off of the pre-trial stage

\begin{tabular}{ccc}
\hline \hline & Firms & Workers \\
No Lawyer & -1234 & 1472 \\
& $(60)$ & $(60)$ \\
Lawyer & -3115 & 2788 \\
& $(131)$ & $(200)$ \\
\hline \hline
\end{tabular}

Notes: 2,486 firms and 2,473 workers (Standard-deviation in the brackets). Standard deviations are computed by delta-method. SETA sample weights are used.

Source: SETA surveys of 1998 and 2003.

Table 22: Marginal Probability from a Probit Regressions on Legal Representation; Firms' surveys

\begin{tabular}{ccc}
\hline \hline Hiring a lawyer & Marginal probability & Predicted value at sample means \\
\hline \hline Non financial cost & $0.10(0.02)$ & 0.39 \\
\hline
\end{tabular}

*The marginal probability is computed from a probit regression for the independent variable: non-financial cost (a dummy equalling one if the firm reports non-financial cost). Dependent variable: lawyer (equalling one if legal expenses are positive for the firm). Non-financial cost is a dummy equalling one if the firm reports nonfinancial cost. Controls include: 2003 year dummy, jurisdictions, union presence at the workplace, local unemployment rate, gender, skills, pay, tenure, age, firm size, sector, industry, region dummies.3,278 observations. SETA sample weights are used. Clustering at the official region level.

Source: SETA surveys of 1998 and 2003. 


\section{CESifo Working Paper Series}

for full list see www.cesifo-group.org/wp

(address: Poschingerstr. 5, 81679 Munich, Germany, office@cesifo.de)

3021 Karl Ove Aarbu, Demand Patterns for Treatment Insurance in Norway, April 2010

3022 Toke S. Aidt and Jayasri Dutta, Fiscal Federalism and Electoral Accountability, April 2010

3023 Bahram Pesaran and M. Hashem Pesaran, Conditional Volatility and Correlations of Weekly Returns and the VaR Analysis of 2008 Stock Market Crash, April 2010

3024 Stefan Buehler and Dennis L. Gärtner, Making Sense of Non-Binding Retail-Price Recommendations, April 2010

3025 Leonid V. Azarnert, Immigration, Fertility, and Human Capital: A Model of Economic Decline of the West, April 2010

3026 Christian Bayer and Klaus Wälde, Matching and Saving in Continuous Time: Theory and 3026-A Matching and Saving in Continuous Time: Proofs, April 2010

3027 Coen N. Teulings and Nick Zubanov, Is Economic Recovery a Myth? Robust Estimation of Impulse Responses, April 2010

3028 Clara Graziano and Annalisa Luporini, Optimal Delegation when the Large Shareholder has Multiple Tasks, April 2010

3029 Erik Snowberg and Justin Wolfers, Explaining the Favorite-Longshot Bias: Is it RiskLove or Misperceptions?, April 2010

3030 Doina Radulescu, The Effects of a Bonus Tax on Manager Compensation and Welfare, April 2010

3031 Helmut Lütkepohl, Forecasting Nonlinear Aggregates and Aggregates with Timevarying Weights, April 2010

3032 Silvia Rocha-Akis and Ronnie Schöb, Welfare Policy in the Presence of Unionised Labour and Internationally Mobile Firms, April 2010

3033 Steven Brakman, Robert Inklaar and Charles van Marrewijk, Structural Change in OECD Comparative Advantage, April 2010

3034 Dirk Schindler and Guttorm Schjelderup, Multinationals, Minority Ownership and TaxEfficient Financing Structures, April 2010

3035 Christian Lessmann and Gunther Markwardt, Decentralization and Foreign Aid Effectiveness: Do Aid Modality and Federal Design Matter in Poverty Alleviation?, April 2010 
3036 Eva Deuchert and Conny Wunsch, Evaluating Nationwide Health Interventions when Standard Before-After Doesn't Work: Malawi's ITN Distribution Program, April 2010

3037 Eric A. Hanushek and Ludger Woessmann, The Economics of International Differences in Educational Achievement, April 2010

3038 Frederick van der Ploeg, Aggressive Oil Extraction and Precautionary Saving: Coping with Volatility, April 2010

3039 Ainura Uzagalieva, Evžen Kočenda and Antonio Menezes, Technological Imitation and Innovation in New European Union Markets, April 2010

3040 Nicolas Sauter, Jan Walliser and Joachim Winter, Tax Incentives, Bequest Motives, and the Demand for Life Insurance: Evidence from two Natural Experiments in Germany, April 2010

3041 Matthias Wrede, Multinational Capital Structure and Tax Competition, April 2010

3042 Burkhard Heer and Alfred Maussner, A Note on the Computation of the Equity Premium and the Market Value of Firm Equity, April 2010

3043 Kristiina Huttunen, Jukka Pirttilä and Roope Uusitalo, The Employment Effects of Low-Wage Subsidies, May 2010

3044 Matthias Kalkuhl and Ottmar Edenhofer, Prices vs. Quantities and the Intertemporal Dynamics of the Climate Rent, May 2010

3045 Bruno S. Frey and Lasse Steiner, Pay as you Go: A New Proposal for Museum Pricing, May 2010

3046 Henning Bohn and Charles Stuart, Population under a Cap on Greenhouse Gas Emissions, May 2010

3047 Balázs Égert and Rafal Kierzenkowski, Exports and Property Prices in France: Are they Connected?, May 2010

3048 Thomas Eichner and Thorsten Upmann, Tax-Competition with Involuntary Unemployment, May 2010

3049 Taiji Furusawa, Kazumi Hori and Ian Wooton, A Race beyond the Bottom: The Nature of Bidding for a Firm, May 2010

3050 Xavier Vives, Competition and Stability in Banking, May 2010

3051 Thomas Aronsson and Erkki Koskela, Redistributive Income Taxation under Outsourcing and Foreign Direct Investment, May 2010

3052 Michael Melvin and Duncan Shand, Active Currency Investing and Performance Benchmarks, May 2010 
3053 Sören Blomquist and Laurent Simula, Marginal Deadweight Loss when the Income Tax is Nonlinear, May 2010

3054 Lukas Menkhoff, Carol L. Osler and Maik Schmeling, Limit-Order Submission Strategies under Asymmetric Information, May 2010

3055 M. Hashem Pesaran and Alexander Chudik, Econometric Analysis of High Dimensional VARs Featuring a Dominant Unit, May 2010

3056 Rabah Arezki and Frederick van der Ploeg, Do Natural Resources Depress Income Per Capita?, May 2010

3057 Joseph Plasmans and Ruslan Lukach, The Patterns of Inter-firm and Inter-industry Knowledge Flows in the Netherlands, May 2010

3058 Jenny E. Ligthart and Sebastian E. V. Werner, Has the Euro Affected the Choice of Invoicing Currency?, May 2010

3059 Håkan Selin, Marginal Tax Rates and Tax-Favoured Pension Savings of the SelfEmployed - Evidence from Sweden, May 2010

3060 Richard Cornes, Roger Hartley and Yuji Tamura, A New Approach to Solving Production-Appropriation Games with Many Heterogeneous Players, May 2010

3061 Ronald MacDonald and Flávio Vieira, A Panel Data Investigation of Real Exchange Rate Misalignment and Growth, May 2010

3062 Thomas Eichner and Rüdiger Pethig, Efficient Management of Insecure Fossil Fuel Imports through Taxing(!) Domestic Green Energy?, May 2010

3063 Vít Bubák, Evžen Kočenda and Filip Žikeš, Volatility Transmission in Emerging European Foreign Exchange Markets, May 2010

3064 Leonid V. Azarnert, Après nous le Déluge: Fertility and the Intensity of Struggle against Immigration, May 2010

3065 William E. Becker, William H. Greene and John J. Siegfried, Do Undergraduate Majors or Ph.D. Students Affect Faculty Size?, May 2010

3066 Johannes Becker, Strategic Trade Policy through the Tax System, May 2010

3067 Omer Biran and Françoise Forges, Core-stable Rings in Auctions with Independent Private Values, May 2010

3068 Torben M. Andersen, Why do Scandinavians Work?, May 2010

3069 Andrey Launov and Klaus Wälde, Estimating Incentive and Welfare Effects of NonStationary Unemployment Benefits, May 2010 
3070 Simon Gächter, Benedikt Herrmann and Christian Thöni, Culture and Cooperation, June 2010

3071 Mehmet Bac and Eren Inci, The Old-Boy Network and the Quality of Entrepreneurs, June 2010

3072 Krisztina Molnár and Sergio Santoro, Optimal Monetary Policy when Agents are Learning, June 2010

3073 Marcel Boyer and Donatella Porrini, Optimal Liability Sharing and Court Errors: An Exploratory Analysis, June 2010

3074 Guglielmo Maria Caporale, Roman Matousek and Chris Stewart, EU Banks Rating Assignments: Is there Heterogeneity between New and Old Member Countries? June 2010

3075 Assaf Razin and Efraim Sadka, Fiscal and Migration Competition, June 2010

3076 Shafik Hebous, Martin Ruf and Alfons Weichenrieder, The Effects of Taxation on the Location Decision of Multinational Firms: M\&A vs. Greenfield Investments, June 2010

3077 Alessandro Cigno, How to Deal with Covert Child Labour, and Give Children an Effective Education, in a Poor Developing Country: An Optimal Taxation Problem with Moral Hazard, June 2010

3078 Bruno S. Frey and Lasse Steiner, World Heritage List: Does it Make Sense?, June 2010

3079 Henning Bohn, The Economic Consequences of Rising U.S. Government Debt: Privileges at Risk, June 2010

3080 Rebeca Jiménez-Rodriguez, Amalia Morales-Zumaquero and Balázs Égert, The VARying Effect of Foreign Shocks in Central and Eastern Europe, June 2010

3081 Stephane Dees, M. Hashem Pesaran, L. Vanessa Smith and Ron P. Smith, Supply, Demand and Monetary Policy Shocks in a Multi-Country New Keynesian Model, June 2010

3082 Sara Amoroso, Peter Kort, Bertrand Melenberg, Joseph Plasmans and Mark Vancauteren, Firm Level Productivity under Imperfect Competition in Output and Labor Markets, June 2010

3083 Thomas Eichner and Rüdiger Pethig, International Carbon Emissions Trading and Strategic Incentives to Subsidize Green Energy, June 2010

3084 Henri Fraisse, Labour Disputes and the Game of Legal Representation, June 2010 